\title{
KONSEP WASIAT WAJIBAH DALAM TAFSIR SURAT AL-BAQARAH AYAT 180
}

\author{
Muhammad Muhajir \\ Universitas Islam Negeri Sunan Kalijaga \\ Email: hajirsyarof@gmail.com
}

\begin{abstract}
This article aims to explain the basic concept of obligatory based on the letter al-Baqarah verse 180. This study uses a statutory approach, a comparative law approach and a conceptual approach. The results of this study indicate that the basic concept of determining the mandatory will is actually of benefit or goodness with istihsān rules that allow the transfer of the law of kulli (general) to juz'i (particular). The assumption of good (istihsān) is essentially goodness which is supported by the textual norms of the verses of the Qur'an. Thus, giving a mandatory will to the granddaughters as happened in the Middle East is very maslahat (good), because they do not get an inheritance share. Likewise, giving mandatory wills to adopted children and non-Muslim heirs is considered good and the fulfillment of a sense of justice in their lives. This provision becomes a lex specialist to make a will during his life with a certain level.
\end{abstract}

Keywords: Obligated Dying Exhortation, Tafsir, Islamic Law

\begin{abstract}
Abstrak
Tulisan artikel ini bertujuan untuk menjelaskan mengenai konsep dasar wajibah berdasarkan surat al-Baqarah ayat 180. Penelitian ini menggunakan pendekatan perundang-undangan, pendekatan perbandingan hukum dan pendekatan konseptual. Hasil penelitian ini menunjukkan bahwa konsep dasar penentuan wasiat wajibah sesungguhnya bernilai kemaslahatan atau kebaikan dengan kaidah istiḥsān yang memungkinkan pemindahan hukum kulli (umum) kepada juz'i (partikular). Anggapan baik (istihssān) hakikatnya ialah kebaikan yang ditunjang oleh norma-norma tekstual ayat al-Qur'an. Dengan demikian memberikan wasiat wajibah kepada para cucu pancar perempuan seperti yang terjadi di Timur Tengah sangatlah maslahat (baik), sebab mereka tidak memperoleh bagian waris. Demikian pula memberikan wasiat wajibah terhadap anak angkat dan ahli waris non muslim dipandang baik dan terpenuhinya rasa keadilan terhadap kehidupan mereka. Ketentuan tersebut menjadi lex spesialis untuk berwasiat semasa hidupnya dengan kadar tertentu.
\end{abstract}

Kata Kunci: Wasiat Wajibah, Tafsir, Hukum Islam

\section{PENDAHUUAN}

Islam adalah ibarat bola salju (snow ball). Semakin lama dan semakin jauh, artinya semakin banyak Islam menyebar dan diimani orang, semakin banyak wajah yang akan muncul, sebagai espresi keberislaman seseorang. Munculnya wajah yang beragam, baik secara 
sinkronis maupun secara diakronis, atau bisa jadi antara setting wilayah geografis dan wilayah lainya, menjadikan Islam disatu tempat berbeda dengan tempat lain. Maka al-Qur'an al-șāliḥ li kulli zamān wa al-makān, sebagaimana gambaran dari Sang Nabi, memberi tantangan mendasar bagi kaum muslimin disepanjang sejarah untukmenemukan cara menjadikan al-Qur'an relevan dengan berbagai situasi dan kondisibaru yang terus berubah. Dalam hal kewarisan, agama memberikan tuntunan dalam kepemilikan harta. Perolehan harta dengan perpindahan melalui waris harus dilakukan dengan cara yang baik dan benar (Wijaya, 2020).

Salah satu ayat yang masih menjadi perdebatan dikalangan ulama adalah surat al-Baqarah ayat 180 yang berbicara tentang kewajiban wasiat. Sebagaian ulama menafsirkan ayat tersebut sudah tidak berlaku lagi setelah adanya ayat tentang waris. Sebagaian ulama yang lain berpendapat bahwa ayat ini tidak dinasakh (hapus) melainkan bersifat muhkam, ada juga yang mengatakan bersifat umum yang mentakhșiș ayat waris.

Pada dasarnya wasiat wajibah berada di antara wasiat dan warisan. Dikatakan seperti itu karena secara ekplisit pewaris tidak pernah mewasiatkan kepada siapa sebagian harta warisanya untuk diwasiatkan. Pranata ini pada dasarnya tidak pernah ditemukan dalam kitab-kitab fikih klasik dan baru muncul pada kitab-kitab fikih modern setelah munculnya Undang-Undang Hukum Perdata Mesir yang menetapkan adanya wasiat wajibah terhadap cucu dari anak perempuan yang tidak berhak mendapatkan harta warisan melalui proses hukum waris.

Pada penelitian sebelumnya yang dilakukan oleh Destri Budi Nugraheni, Haniah Ilhami, dan Yulkarnain Harahab pada tahun 2010 (Desti Budi Nugraheni, Haniah Ilhami, 2010), membahas pengaturan dan implementasi wasiat wajibah di Indonesia. Penelitian tersebut menganalisis sifat pengaturan wasiat wajibah dalam Kompilasi Hukum Islam dan implementasinya dalam pengadilan agama. Adapun penelitian lain yang serupa dilakukan oleh Muhammad Iqbal Piliang, M. Najib Tsauri pada tahun 2019 (Piliang \& Tsauri, 2019) yang membahas wacana waris yang didasarkan pada ayat-ayat al-Qur'an menurut penafsir modern, Muhammad Shaḥūur dengan Munawir Sjadzali. Kedua penafsir ini diangkat karena keduanya dapat dianggap telah berusaha dalam konteksnya masing-masing untuk menjawab munculnya sikap ambigu dalam mengimplimentasikan hukum waris dari kalangan masyarakat muslim.

Di Indonesia wasiat wajibah diperuntukan untuk anak angkat, bapak angkat maupun ahli waris non muslim. Hal ini sangat berbeda dengan apa yang ditetapkan oleh Undang-Undang Perdata Mesir. Artikel ini memfokuskan tentang bagaimana konsep wajibah dalam tafsir surat 
al-Baqarah ayat 180 berbicara pada konteks kekinian. Sehingga penelitian ini bertujuan untuk mendiskripsikan dan menjelaskan konsep wajibah dalam tafsir surat al-Baqarah ayat 180 .

\section{METODE PENELITIAN}

Jenis penelitian yang digunakan dalam menyusun penelitian ini adalah penelitian kepustakaan dan menggunakan pendekatan perundangundangan (statute approach), pendekatan perbandingan hukum dan pendekatan konseptual (concept approach). Sumber data yang digunakan adalah data sekunder berupa buku-buku atau literatur, jurnal ilmiah, dan, peraturan perundang-undangan yang ada hubungannya dengan masalah yang dibahas.

\section{PEMBAHASAN}

\section{Teks Ayat dan Terjemah}

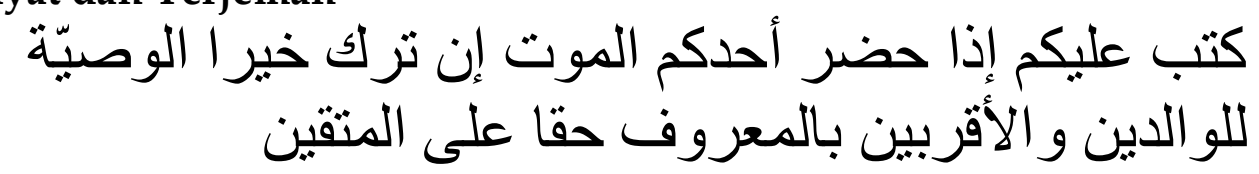

Artinya : "Diwajibkan atas kamu, apabila seorang diantara kamu kedatangan (tanda-tanda) kematian, jika ia meninggalkan harta yang banyak, berwasiat untuk ibu-bapak dan kerabatnya secara baik, (ini adalah) kewajiban atas orang-orang yang bertakwa."(Q.S. Al-Baqarah : 180).

\section{Kutiba}

Kata "kutiba" merupakan bentuk lain dari fi'il māḍi "kataba". Menurut al-Dāmaghānī (Damaghani, 1983:400-401) bahwa kata "kataba" yang digunakan dalan Al-Qur'an menunjukan hanya ada empat makna, yaitu: furiḍa (diwajibkan), qudiya (ditetapkan), ju il (dijadikan), umira (diperintahkan). Adapun khusus pada Q.S. 2: 180 kata tersebut dimaknai sebagai furida, artinya diwajibkan kepada orang yang kedatangan tanda-tanda kematian untuk berwasiat kepada ibu-bapak dan kerabatnya dengan batas maksimal sepertiga (Al-Zuhaili, 2009). Meskipun selanjutnya terdapat perbedaan pendapat dikalangan para ulama atas dinasakh dan tidaknya ayat tersebut.

\section{Wașiyyah}

Kata al-wașiyyah yang muncul dalam fi'il mādi ada tiga macam, yaitu: wașșa, awșa dan tawașaw. Kata wașșa dipakai untuk beberapa arti diantaranya; mewasiatkan, menetapkan, memerintahkan, dan mewajibkan. Selanjutnya kata al-wașiyyah muncul dalam bentuk awșamempunyai makna memerintahkan. Kemudian bentuk fi'il muḍari' dari awșa seperti yūṣūna, yūṣìna, atau yūși yang berarti mensyari'atkan dan membuat wasiat muncul empat kali dalam surat al-Nisa' ayat 11 dan 12. Sedangkan kata al-wașiyyah dalam bentuk tawāṣaw yang berarti 
saling berpesan muncul empat kali dalam surat al-Żāriyāt ayat 53, surat al-Balad ayat 17 dan surat al-'Așr ayat 3. Kata al-wașiyyah dalam bentuk ism al-fä'il yaitu mūșin menunjukan arti orang yang berwasiat mucul satu kali dalam surat al-Baqarah ayat 182. Sedangkan kata yang berbentuk taușiyyah yang berarti menunjukan proses pembuatan suatu wasiat muncul sekali dalam surat Yasin ayat 50 (Junaidi, 2013).

a. Asbab al-Nuzul Ayat

Sebab turunya ayat ini adalah kebiasan masyarakat Arab jahiliyyah mewasiatkan harta mereka kepada orang-orang yang jauh dengan tujuan kesombongan dan meninggalkan kerabat dekatnya dalam keadaan fakir dan miskin karena sebab permusuhan dan perselisihan. Oleh karena itu Allah menurunkan ayat ini untuk mengembalikan hak-hak sanak kerabat dekat yang telah diberikan kepada orang-orang yang jauh (Ibn 'Asyur, 2005).

b. Munāsabah Ayat

Ditinjau dari segi materinya dalam al-Qur'an sekurangkurangnya terdapat tujuh macam munāsabah. Salah satunya yakni keterkaitan satu ayat dengan ayat lain dalam satu surat(MKD, 2014). Jika diperhatikan, Q.S. al-Baqarah (2) : 180 ini berkaitan erat dengan ayat sebelumnya, yaitu ayat 178 dan 179 .

Menurut Quraish Shihab Munāsabah al-Qur'an diketahui berdasarkan ijtihad, bukan dari petunjuk Nabi SAW (tawqifi). Setiap orang bisa saja menghubung-hubungkan antara berbagai hal di dalam kitab al-Qur'an (Shihab, 1999 : 77). Oleh karena itu menurut Wahbah alZuhaili, pada Q.S. al-Baqarah (2) : 178 -179 telah dikemukan masalah hukum qișās di dalam pembunuhan dan diat. Kemudian diiukuti ayat tentang peringatan untuk wasiat yang diwajibkan dari Tuhan kepada hamba-Nya agar seseorang yang akan meninggal dunia tidak sampai melupakan wasiat (Al-Zuhaili, 1998). Sedangkan menurut Mustafa alMaraghi, keterkaitan Q.S. al-Baqarah (2) : 180 dengan ayat sebelumnya ialah ayat sebelumnya telah menerangkan masalah hukum qiṣās di dalam pembunuhan. Qișās merupakan salah satu jalan kematian. Adalah wajar jika ayat setelahnya membicarakan wasiat bagi seorang yang sudah diambang kematian (Al-Maraghi, 1984).

3. Tafsir Ayat

Ayat ini menunjukan keumuman perintah berwasiat bagi seseorang yang telah kedatangan tanda-tanda kematian. Tanda-tanda hadirnya kematian di antaranya adalah rambut yang memutih, gigi yang rontok, kesehatan yang menurun, usia senja, dan lain sebagainya. Wasiat adalah pesan baik yang disampaikan kepada orang lain untuk dikerjakan, baik saat hidup atau setelah kematian yang berpesan (Ibn 'Asyur, 2005). Tetapi menurut Quraish shihab wasiat bisa digunakan 
untuk pesan-pesan yang disampaikan untuk dilaksanakan setelah kematian yang memberi wasiat (Shihab, 2002).

Kewajiban wasiat menurut kebanyakan ulama didasarkan pada kata kutiba yang bermakna wajib, apalagi penutup ayat ini menegaskan bahwa itu adalah hak. Namun di sini ada perbedaan pendapat setelah turunya ayat tentang hak waris. Menurut jumhūr ulama ayat ini di nasakh dengan ayat mawaris sehingga ayat ini tidak berlaku lagi, kendati sebelumya adalah wajib.

Ulama yang mengatakan tidak ada ketentuan wasiat wajibah dalam mengemukakan ketidakberlakuannya dapat dikategorikan dalam beberapa kelompok:

a. Kelompok yang menyatakan bahwa ketentuan wasiat wajibah dalam ayat 180 surat al-Baqarah tidak dapat diberlakukan karena ayat tersebut telah di nasakh oleh ayat-ayat waris. Ibnu katsir dalam tafsirnya mengatakan bahwa ketika turun ayat-ayat faraid, ayat wasiat tersebut dinasakh (Katsir, 1994) Al-Razi menyatakan pendapat yang seperti ini kebanyakan dikemukakan oleh mufassir dan ahli fiqh yang sudah diakui. (Al-Razi, 1995) Demikian juga pendapat ini dikuatkan para ulama seperti al-Hasan, Qatadah, Tawus, dan Jabir bin Zayd.

b. Kelompok yang menyatakan ayat ini dinaskah oleh hadis lā waiyyata li waris,bukan ayat-ayat waris. Menurut hadis Nabi SAW ayat wasiat ini terhapus dengan diberikanya hak waris kepada masing-masing ahli waris oleh Allah SWT (Al-Razi, 1995).

c. Kelompok yang menyatakan ayat ini tidak dapat diberlakukan karena telah dinasakh oleh ayat waris dan hadis Rasulullah SAW. Pendapat ini diantaranya dikemukakan oleh al-Baidlawi yang menyatakan ayat ini dihapus oleh ayat waris dan hadis riwayat Tirmidzi (M.Rashid Rida, 1975).

d. Kelompok yang menyatakan bahwa ketentuan wasiat wajibah telah dinasakh oleh ijma'. Sehingga kewajiban wasiat bagi orang tua dan kerabat tersebut juga telah dinasakh oleh ijma' (Katsir, 1994).

Sebagian ulama berpendapat wasiat tetap berlaku dengan menolak ide adanya pembatalan ayat-ayat hukum al-Qur'an. Mereka tetap berpegang kepada ayat ini dalam arti wajib. Kelompok ini menyatakan bahwa seluruh ayat al-Qur'an adalah muhakkamah, artinya tidak ada naskh (nasikh mansukh) dalam al-Qur'an. Jadi ayat 180 surat alBaqarah tersebut tidak dinasakh (dihapus atau dihilangkan hukumnya), baik oleh ayat-ayat mawaris (al-Qur'an) atau hadis (Makhluf, 1959) Abu Muslim Al-Asfahani mengatakan bahwa ayat ini tidak dinasakh akan tetapi justru ditafsirkan oleh ayat-ayat mawaris (Al-Razi, 1995) dengan penjelasan sebagai berikut: (1) Bahwa ayat ini berbeda dengan ayat mawaris, maksudnya adalah bahwa wasiat yang diberikan kepada 
orang tua dan kerabat tidak mengurangi sedikitpun bagian mereka dalam pembagian harta waris. (2) Tidak ada saling meniadakan antara ketetapan waris untuk kerabat dengan ketetapan wasiat sebagai pemberian bagi orang yang akan meninggal, sehingga ahli waris (orang tua dan kerabat) dapat mengumpulkan dua bagian (dari bagian waris dan wasiat) secara bersamaan dengan bedanya hukum dua ayat ini. (3) Seandainya peniadaan diberlakukan maka ayat waris berfungsi sebagai pentakhsis bagi ayat 180 surat al-Baqarah, karena ayat ini mewajibkan wasiat bagi kerabat, sedangkan ayat waris mengeluarkan kerabat ahli waris dan hak wasiat sehinga otomatis hanya bukan ahli waris saja yang masuk ke dalam ayat wasiat ini. Demikian juga dengan kedua orang tua, ada yang berhak mewarisi dan tidak oleh satu dan lain hal, seperti adanya perbedaan agama, perbudakan, atau karena pembunuhan.

Rashid Rida menyatakan bahwa ayat wasiat tidak dinasakh dengan ayat-ayat waris karena tidak ada pertentangan diantara keduanya bahkan saling menguatkan. Tidak ada petunjuk bahwa ayat waris tersebut turun setelah ayat wasiat, tidak juga dinasakh dengan hadis karena hadis tidak dibenarkan menasakh al-Qur'an. Ayat tersebut muhkamat dan hukumnya tetap (M. Rashid Rida, 1975).

Sebagian ulama yang lain mengatakan bahwa ayat wasiat tersebut bersifat umum, yakni meliputi orang tua dan kerabat, ditakhsis oleh ayat waris (ayat 11 dan 12 surat an-Nisa') dan hadis yang menyatakan tidak ada wasiat bagi ahli waris. Jadi menurut mereka ayat 180 surat al-Baqarah tersebut hanya berlaku untuk orang tua dan kerabat yang menurut ketentuan umum pewarisan tidak mendapatkan bagian harta peninggalan pewaris. Sedangkan orang tua dan kerabat yang mendapatkan warisan dikeluarkan oleh keumuman ayat wasiat di atas.

Diantara kelompok ini adalah pendapat Sa'id ibnu Jubair, arRabi' ibnu Anas, Qatadah, dan Muqatil ibnu Hayyan, pendapat mereka ini menurut peristilahan di kalangan ulama mutaakhkhirin bukan dinamakan nasakh, karena ayat mawaris hanyalah menghapus sebagian hukum yang ditunjukkan oleh keumuman makna ayat wasiat. Mengingat istilah kaum kerabat mencakup orang-orang yang mempunyai hak waris dan orang-orang yang tidak mempunyai hak waris, maka dihapuslah hukum yang menyangkut orang-orang yang berhak mewaris karena telah ada bagian tertentu baginya, sedangkan untuk yang lainnya yang tidak mempunyai bagian tertentu, misalkan orangtua non muslim atau kerabat yang tidak mendapat warisan, mereka tetap mendapatkan wasiat berdasarkan apa yang ditunjukkan oleh ayat pertama (al-Baqarah ayat 180) (Katsir, 1994). 
Ada juga kelompok yang menyatakan ayat 180 surat al-Baqarah tersebut dinasakh oleh ayat waris, tetapi hanya sebagian, yakni sebatas orang tua dan kerabat yang mendapatkan harta peninggalan. Di antara yang berpendapat demikian adalah Ibnu Abbbas, al-Hasan, Masruq, alDahhak, Muslin bin Yasar, dan al-'Ala ibnu Ziyad. Jadi ayat tersebut masih berlaku bagi orangtua dan kerabat yang tidak menjadi ahli waris/tidak menerima bagian warisan (Katsir, 1994).

Adapun maksud dari (intaraka khairan) tidak ada perbedaan pendapat di antara para ulama, mereka sepakat bahwa yang dimaksud dengan khairan adalah harta seperti yang disebutkan dalam surat AlBaqarah ayat 272 dan al-'Ādiyāt ayat 8. Sedangkan harta yang diwasiatkan itu sendiri terdapat perbedaan pendapat. Ada yang mengatakan bahwa tidak membedakan antara harta baik sedikit atau banyak, dan ini adalah pendapat Az-Zuhri, maka wasiat diwajibkan untuk semua harta. Adapun yang dijadikan dalil adalah pertama bahwa sesungguhnya Allah mewajibkan wasiat dalam sesuatu jika yang ditinggalkan itu baik, sedangkan harta sedikit itu baik, adapun yang dijadikan dasar adalah Al-Qur'an surat al-Zalzalah ayat 7-8 dan Q.S. al-Qoșoṣ ayat 24. Dalil yang kedua adalah bahwa Allah telah menetapkan beberapa hukum tentang kewarisan bagi harta baik sedikit maupun banyak, seperti firman Allah ayat 7 surat An-Nisa'.

Pendapat yang kedua mengatakan bahwa yang dimaksud khairan adalah harta yang banyak. Oleh karena itu, jika harta peninggalan hanya sedikit maka tidak wajib wasiat (Ibn 'Asyur, 2005). Adapun batas yang wajib untuk diwasiatkan adalah 800 dirham menurut pendapat Ibnu Abbas dan 1000 dirham menurut pendapat Qatadah. (Al-Zuhaili, 2009). Sementara menurut Quraish shihab harta yang banyak merupakan hal yang relatif. Al-Qur'an dan Sunnah tidak menjelaskan spesifik berapa jumlahnya sehingga sementara ulama berpendapat bahwa wasiat dianjurkan atau diwajibkan berapapun jumlah harta yang dimiliki (Shihab, 2002).

Makud dengan ayat (lil walidaini wal aqrobina), yaitu mewajibkan berwasiat untuk kedua orang tua dan kerabat dekat, akan tetapi setelah turunya ayat tentang waris, maka ayat ini termansukh. Menurut Abu Hanifah yang dimaksud dengan kerabat adalah setiap orang yang mempunyai pertalian darah baik dari bapak maupun ibu, akan tetapi dihitung mulai ayah sebelum ibu (Al-Asqalani, 1995). Dikalangan Syafi'iyah mengatakan yang dimaksud kerabat adalah yang berkumpul dalam satu nasab baik itu jauh atau dekat, muslim atau kafir, kaya atau fakir, laki-laki atau perempuan, ahli waris atau bukan, mahram atau bukan mahram. Pendapat Ahmad bin Hambal tentang kerabat identik dengan Imam Syafi'i, hanya saja isa mengecualikan orang kafir. Sedangkan imam Malik hanya mengkhususkan bagi așabah baik yang 
dapat mewarisi atau tidak, dimulai dari yang miskin sehingga hidupnya menjadi berkecukupan kemudian baru diberikan kepada yang kaya (Al-Asqalani, 1995).

Maksud dari (bil ma'ruf) adalah wasiat itu dilakukan dengan cara yang adil. Maksud dari adil sendiri adalah pembagian yang tidak menimbulkan kecemburuan di antara kerabat dengan mempertimbangkan segi-segi kebaikan, kemaslahatan, dan kewajaran yang sehat. Tidak memberikan harta kepada si kaya dan menelantarkan si miskin atau dengan kata lain mengutamakan mereka yang sangat membutuhkan (Al-Asqalani, 1995).

Menurut ibnu Katsir yang dimaksud dengan cara yang makruf ialah hendaknya dia berwasiat untuk kaum kerabatnya suatu wasiat yang tidak menghabiskan bagian ahli warisnya, yakni tidak berlebihlebihan dan tidak pula terlalu pelit. Seperti yang disebutkan di dalam hadis Sahihain, yaitu Bahwa Sa'd bertanya, "Wahai Rasulullah, sesungguhnya aku mempunyai harta yang banyak, sedangkan aku tidak mempunyai ahli waris selain anak perempuanku, maka bolehkah aku berwasiat dengan dua pertiga hartaku?" Rasul Saw. menjawab, "Tidak." Sa'd bertanya, "Bagaimana dengan separonya?" Rasul Saw. menjawab, "Tidak." Sa'd bertanya, "Bagaimana dengan sepertiga?" Rasul Saw. menjawab, "Sepertiga, ya sepertiga cukup banyak. Sesungguhnya kamu jika meninggalkan ahli warismu dalam keadaan berkecukupan, jauh lebih baik daripada kamu tinggalkan mereka dalam keadaan miskin meminta-minta kepada orang lain." (Katsir, 1994).

4. Qira'ah al-Muntijah / Penafsiran Ayat dalam Konteks Kekinian

Istilah wasiat wajibah dipergunakan pertama kali di Mesir melalui Undang-Undang Hukum Waris 1946 untuk menegakkan keadilan dan membantu cucu yang tidak memperoleh hak warisanya(Al-Amruzi, 2012). Ketentuan hukum ini bermanfaat bagi anak-anak dari anak-anak laki-laki yang meninggal (ibn al-ibn) dan seterusnya kebawah. Sedangkan untuk garis perempuan hanya berlaku untuk anak dari anak perempuan saja tidak berlanjut sampai generasi selanjutnya. Selain Mesir, diberlakukan pula di negara-negara yang mayoritas muslim seperti Tunisia, Yordania, Syiria, termasuk Indonesia.

Pendapat yang menyatakan bahwa wasiat wajibah yang ada di Indonesia sebagaimana yang tersebut dalam Kompilasi Hukum Islam adalah adopsi pemahamanhukum yang ada di Mesir bisa dikatakan ada benarnya hanya wasiat wajibah di siniditujukan bukan pada anak angkat tetapi untuk membantu para cucu pancar lelakiterlebih bagi cucu pancar perempuan.

Kompilasi Hukum Islam tidak hanya membatasi persoalan pada para cucu tetapi juga terhadap anak angkat yang jelas bukan memiliki 
kekerabatan apapun sekalipun jauh. Mereka akan mendapat bagian wasiat wajibah sebagaimana para cucuyang memungkinkan beroleh wasiat wajibah. Sebagaimana tersebut dalam pasal 209:

a. Harta peninggalan anak angkat dibagi berdasarkan pasal 176 sampai denganpasal 193 tersebut di atas, sedangkan terhadap orang tua angkat yang tidakmenerima wasiat diberi wasiat wajibah sebanyak-banyaknya 1/3 dari hartawarisan anak angkatnya.

b. terhadap anak angkat yang tidak menerima wasiat diberi wasiat wajibah

sebanyak-banyaknya $1 / 3$ dari harta warisan orang tua angkatnya.

Pasal 209 ayat (2) di atas memberikan gambaran bahwa anak angkat dapat menerima wasiat wajibah sebanyak 1/3 dari harta warisan orang tua angkatnya. Secara sosiologis, kebanyakan dimasyarakat, pasangan suami istri yang tak memiliki keturunanlah yang biasanya mengangkat anak orang lain sebagai anak angkat. Kebanyakan di Indonesia, anak angkat diangkat sebagai anak sejak kecil, dipelihara bahkan dikasih sayangi layaknya sebagai anak sendiri. Persoalannya adalah dalam beberapa kasus ketika orang tua angkatnya telah meninggal dunia, anak angkat yang belum dewasa justru terlantar hidupnya. Sementara saudara orang tua angkat akan datang dan mengambil harta peninggalan orang tua angkat tampa memperdulikan nasip anak angkat. Alasan mereka didasarkan pada hukum kewarisan bahwa anak angkat bukanlah ahli waris dari orang tua angkatnya. Berdasar norma inilah, beberapa kasus terlantarnya anak angkat dan tidak adanya pembelaan terhadap mereka memungkinkan timbulnyapemikiran untuk melindungi mereka (AlAmruzi, 2012).

Konsep dasar dari Pasal 209 ayat (2) di atas bahwa wasiat mengutamakan orang lain yang bukan ahli waris. Sebagaimana hadis Nabi "Allah memberi setiap yang berhak akan haknya maka tidak ada wasiat untuk para waris" (HR. Bukhari). Disini anak angkat dapat dikategorikan sebagai orang lain.

Konsep wasiat harta dalam Islam ditujukan kepada kerabat jauh atau kerabat yang tak mendapat hak peroleh waris dan juga terhadap orang lain. Dari pemahaman inilah berkembang teori penalaran hukum atas hukum wasiat sehinggasampai padapenalaran tentang kedudukan hukumnya. Terakhir menyangkut wasiat wajibah. Yaitu kapan wasiat wajibah terjadi dan mengapa ia mesti diadakan. Atas dasar ini pula Kompilasi Hukum Islam menunjukwasiat wajibah terjadi pada anak angkat bukan pada cucu seperti yang ada di Mesirdan umum negara mayoritas Islam di Timur Tengah. Sebab para cucu dalamKompilasi Hukum Islam telah mendapat bagian mereka melalui waris pergantian. 
Istiḥsān menurut bahasa adalah dari kata bentukan (musytaq) yaitu al-hasan (apapun yang baik dari sesuatu) sehingga menganggap sesuatu itu baik. Menurut Wahbah Al-Zuhaili, Imam Hanafi memberi makna denga sesuatu keadaan darurat yang mengambil kebaikan atatu istị̣sān bi al-maslaḥāt yaitu istiḥsān dengan maksud kebaikan.(AlAmruzi, 2012).

Metode istihsān sangat efektif untuk membedah persoalan wasiat wajibah. Baik dalam ranah al-Qur'an dan hadis maupun studi dikalangan yuris Islam klasik yang tidak ditemukan istilah wasiat wajibah. Bahkan dalam legislasi modern hukum Islam di Timur Tengah wasiat wajibah berbeda objeknya dengan yang ada di Indonesia. Pada studi wasiat wajibah di Timur Tengah wasiat wajibah ditunjukan untuk kepentingan cucu dari anak perempuan yang tidak berhak mendapatkan harta warisan melalui proses hukum waris. Tetapi di Indonesia wasiat wajibah diperuntukan untuk anak angkat, bapak angkat maupun ahli waris non muslim.

Dasar penentuan wasiat wajibah terhadap anak angkat adalah suatu kemaslahatan atau kebaikan dengan kaidah istiḥsān yang memungkinkan pemindahan hukum kulli (universal;umum) kepada juz'i (partikular). Metode ini secara mudah dapat dipahami bahwa teks Q.S al-Baqarah ayat 180 tetap memiliki eksistensinya bukan dimansukh (dihapus) oleh ayat kewarisan (an-Nisa' ayat 11, 12 dan 176) tetapi ayat tersebut menjadi kulli (universal). Sedangkan Q.S An-Nisa' ayat 11, 12 dan 176 adalah juz'i (partikular). Ia menjadi lex spesialis bagi mereka yang berketurunan tanpa melarang orang untuk berwasiat semasa hidupnya dengan kadar tertentu.

Bagian yang kedua dari istihsān adalah berdasarkan sandaran dalil yaitu norma dasar hukum al-Qur'an yang dianggap lebih kuat dari dalil lain misalnya mengambil kebaikan dari sesuatu yang dibolehkan. Seperti dalam kasus anak angkat, dari pada surat an-Nisa' ayat 11, 12 dan 176 tidak memberikan hak kepada anak angkat maka dengan mengambil dalil Q.S al-Baqarah ayat 180 adalah menguatkan diberlakukanya wasiat wajibah terhadap orang yang dalam pemeliharaan yaitu anak angkat. Walaupun demikian syarat jumlah yang tidak boleh melebihi 1/3 (sepertiga) dari harta warisan orang tua angkatnya dengan maksud untuk melindungi ahli waris lainnya (Setiawan, 2017).

Konsep selanjutnya, anggapan baik (istihsān) adalah kebaikan yang ditunjang oleh norma-norma tekstual ayat. Dan menurut teks yang banyak dalam al-Qur'an adalah kemaslahatan maka ia boleh diambil untuk suatu kemaslahatan selama tidak ada dalil yang melarangnya. Seperti petunjuk teks normatif al-Qur'an Q.S al-Zumar ayat 18 "yang mendengarkan perkataan lalu mengikuti apa yang paling baik 
di antaranya. Mereka itulah orang-orang yang telah diberi Allah petunjuk dan mereka itulah orang-orang yang mempunyai akal."

Ketentuan Pasal 209 KHI menaunjukkan bahwa sistem hukum kewarisan Islam memberikan ruang eksistensi Wasiat Wajibah. Ketentuan tersebut mengatur mengenai pihak-pihak yang berhak untuk mendapatkan Wasiat Wajibah dengan jumlah tertentu. Jika terdapat kebuntuan hukum dalam menentukan Wasiat Wajibah maka dapat digunakah kaidah untuk mengisi kekosongan hukum dengan berlandaskan pada aturan wasiat secara umum yang dapat memenuhi rasa keadilan (Desti Budi Nugraheni, Haniah Ilhami, 2010)

Memberikan wasiat wajibah kepada para cucu pancar perempuan seperti yang terjadi di Timur Tengah sangatlah maslahat (baik) sebab mereka tidak memperoleh bagian waris. Demikian pula memberikan wasiat wajibah terhadap anak angkat dipandang baik terhadap kehidupan mereka bahkan oleh lingkungan sosial. Sedang kebaikan itu dianjurkan Tuhan dan tidak terlarang melakukanya. Nabi Muhammad mengatakan "Sesuatu yang dipandang kaum muslimin itu baik, maka menurut Allah juga baik." (H.R. Ahmad)

Selain wasiat wajibah diperuntukan untuk anak angkat, belakangan juga wasiat wajibah digunakan untuk memberi keadilan kepada ahli waris non muslim. Contoh putusan Mahkamah Agung No.368 K/AG/1995, putusan Mahkamah Agung No. 51.K/AG.1999, dan putusan Mahkamah Agung No. 16K/Ag/2010 sebagai yurisprudensi di lingkungan Peradilan untuk memberikan hak kepada ahli waris non muslim. Majelis Hakim pada Mahkamah Kasasi berpendapat bahwa, ahli waris yang bernon muslim dengan pewaris, dapat memperoleh pusaka melalui jalan wasiat wajibah. Sedangkan nasikh-mansükh ayat wasiat dengan waris, berlaku untuk sementara waktu. Ketika ayat hukum yang dinasakh tersebut dapat membawa kemaslahatan dan terciptanya keamanan serta kesejahteraan masyarakat, maka hukum tersebut berlaku kembali (Zaid, 2016).

Pemberian bagian wasiat wajibah bagi anggota keluarga non muslim menjadi hal yang sepatutnya ditegakkan, apalagi di Indonesia terdapat ratusan kelompok-kelompok etnis yang hidup dalam kawasan territorial tersendiri dengan bahasa, sistem sosial budaya yang berbeda-beda,sehingga perlu dipertimbangkan bahwa ahli waris non muslim bagaimanapun juga adalah suami/istri atau anak pewaris, maka tentulah wajar bila mengharapkan memperoleh bagian dari harta pewaris. Walaupun secara formal ahli waris non muslim tidak berkedudukan sebagai ahli waris, maka dirasa adil dan wajar jika hakim mendudukkan mereka sebagai penerima wasiat wajibah dari orang tuanya atau suami/istri yang muslim melalui wasiat wajibah. 
Sebagai perbandingan terdapat teori batas yang digagas oleh Shaḥūr dengan memperhatikan teori batas maksimal dan batas minimal. Hal tersebut dianggap sesuai asas keadilan berimbang dalam upaya pembaharuan hukum Islam sesuai dengan kondisi yang melingkupinya. Dalam konteks kewarisan di Indonesia, masyarakat Indonesia punya sikap dalam menyelesaikan persoalan keagamaan dibidang kewarisan dengan situasi kontemporer mengadaptasikan ayat-ayat al-Qur'an dengan perkembangan zaman yang dianggap "lebih adil"(Piliang \& Tsauri, 2019). Gotong royong antara istri dan suami dalam memenuhi kebutuhan hidup mampu mengubah pembagian waris yang awalnya laki-laki dua kali lebih besar dari perempuan menjadi sama besarnya. Hal itu terjadi karena ada pergeseran implikasi tanggungjawab penuh pihak laki-laki sebagai suami yang berorientasi pada kemaslahatan bersama.

Aspek pluralitas hukum/norma akan muncul dari perkembangan budaya dan peradaban yang hidup di masyarakat. Rasa keadilan yang hendak dicapai tenntu berbeda berdasarkan pada masyarakat tertentu dilokasi dan waktu tertentu juga (Hadi, 2017). Menurut hemat penulis, konsep wasiat wajibah ini ke depan dapat diterapkan kepada siapa saja yang dianggap berhak menerima wasiat dengan melihat kemaslahatan bersama. Sehingga dengan begitu tercipta hukum yang responsif dan berkeadilan di masyarakat.

\section{SIMPULAN}

Hasil dari pembahasan penelitian ini dapat disimpulkan bahwa dasar penentuan wasiat wajibah terhadap anak angkat dan ahli waris non muslim adalah suatu kemaslahatan atau kebaikan dengan kaidah istihsān yang memungkinkan pemindahan hukum kulli (universal;umum) kepada juz'i (partikular). Metode ini secara mudah dapat dipahami bahwa teks Q.S al-Baqarah ayat 180 tetap memiliki eksistensinya bukan dimansukh (dihapus) oleh ayat kewarisan.

Anggapan baik (istihsān) selanjutnya adalah kebaikan yang ditunjang oleh norma-norma tekstual ayat, selama tidak ada dalil yang melarangnya. Memberikan wasiat wajibah kepada para cucu pancar perempuan seperti yang terjadi di Timur Tengah sangatlah maslahat (baik) sebab mereka tidak memperoleh bagian waris. Demikian pula memberikan wasiat wajibah terhadap anak angkat dan ahli waris non muslim dipandang baik dan terpenuhinya rasa keadilan terhadap kehidupan mereka. Konsep wasiat wajibah ini ke depan dapat diterapkan kepada siapa saja yang dianggap berhak menerima wasiat dengan melihat kemaslahatan bersama. Sehingga dengan begitu tercipta hukum yang responsif dan berkeadilan di masyarakat sesuai dengan pesan yang tersirat dari Q.S al-Baqarah ayat 180 . 


\section{DAFTAR PUSTAKA}

\section{Buku-buku}

Al-Amruzi, F. (2012). Rekonstruksi Wasiat Wajibah dalam Kompilasi Hukum Islam. Aswaja.

Al-Asqalani. (1995). Fath al-Kabir. Dar al-Ma'rifah.

Al-Zuhaili, W. (1998). Al-Burhan Juz 2. Dar al-Fikr al-Mu'asirah.

Al-Zuhaili, W. (2009). Tafsīr al-Munīr fi al-'Aqīdah wa al-Syarī’ah wa alManhaj (D. Al-Fikr (ed.).

Ibn 'Asyur. (2005). Tafsir al-Tarīr wa al-Tanwiīr, Juz 2 (D. At-Tunisiah (ed.)).

Junaidi, A. (2013). Wasiat Wajibah: Pergumulan Antara Hukum Adat dan Hukum Islam di Indonesia (P. Pelajar (ed.)).

Katsir, I. (1994). Tafsir Ibnu Katsir Juz 1. Dar al-Kitab al-'Alamiyyah.

M.Rashid Rida. (1975). Tafsir al-Manar. Dar al-Fikr.

Makhluf, H. M. (1959). Al -Mawaris fi al-Syari'ah al-Islamiyah. Lajnah alBayan al-'Arabi.

MKD, T. R. (2014). Studi Al-Qur'an. UIN Sunan Ampel Press.

\section{Jurnal-jurnal}

Desti Budi Nugraheni, Haniah Ilhami, Y. H. (2010). Pengaturan dan Implementasi Wasiat Wajibah di Indonesia. Mimbar Hukum Fakultas Hukum Universitas Gadjah Mada, 22(2), 311-329. https://doi.org/10.22146/jmh.16229

Hadi, S. (2017). Pembatasan Wasiat Sebagai Bentuk Keadilan Hukum Islam. Al-Ahwal: Jurnal Hukum Keluarga Islam, 9(2), 169. https://doi.org/10.14421/ahwal.2016.09203

Piliang, M. I., \& Tsauri, M. N. (2019). Penafsiran Modern Ayat-Ayat Waris: Perbandingan Muammad Sharūr dan Munawir Sjadzali. Refleksi, 18(1), 78-116. https:/ / doi.org/10.15408/ref.v18i1.12677

Setiawan, E. (2017). Penerapan Wasiat Wajibah Menurut Kompilasi Hukum Islam (KHI) Dalam Kajian Normatif Yuridis. Muslim Heritage, 2(1),

43. https://doi.org/10.21154/muslimheritage.v2i1.1045

Wijaya, W. P. (2020). Ayat-Ayat Waris dalam Tinjauan Tafsir Maudhu'i dan Penyimpangannya di Indonesia. Wardah, 21(1), 106-122. https://doi.org/10.19109/wardah.v21i1.5826 
Muhammad Muhajir

Halaman ini sengaja dikosongkan 